\title{
Reference Values of the Central Corneal Thickness with Different Refractive Errors for the Adult Egyptian Population
}

This article was published in the following Dove Press journal: Clinical Ophthalmology

\author{
Amr A Gab-Alla (iD \\ Suez Canal University, Faculty of \\ Medicine, Ophthalmology Department, \\ Ismailia, Egypt
}

Aim: To generate reference values of the central corneal thickness (CCT) with different refractive errors for the adult eastern Egyptian population.

Subjects and Methods: This study was a retrospective, observational, and cross-sectional study. It included 1166 eyes (1166 subjects) scheduled for LASIK, who came to private refractive eye centre, Ismailia, Egypt. The study period was from January 2018 to January 2020. The subjects were divided into a broad range of myopia with spherical equivalent (SE) $\leq-0.5 \mathrm{D}$ and hyperopia $(\mathrm{SE}) \geq+0.5 \mathrm{D}$. Then, the myopic eyes divided into low (SE $>-3.0 \mathrm{D}$ ), moderate (SE-3.0D to $>-6.0 \mathrm{D}$ ), and high $(\mathrm{SE} \leq-6.0 \mathrm{D})$. Similarly, the hyperopic eyes were divided into low $(\mathrm{SE}<+3.0 \mathrm{D})$ and moderate $(\mathrm{SE}+3.0 \mathrm{D}$ to $<+6.0 \mathrm{D})$ and high $\geq+6.0 \mathrm{D}$. The refractive error was measured by an auto-refractometer, and CCT was measured using ultrasonic pachymetry.

Results: The data of 556 myopic eyes in 556 subjects (31.1\% males and $68.9 \%$ females) and 610 hyperopic subjects $(34.4 \%$ males and $65.6 \%$ females $)$ were included in this study. The mean $\pm \mathrm{SD}$ of CCT for the total myopic subjects was $532.8 \pm 32.6 \mu \mathrm{m}$, range (470 to $627 \mu \mathrm{m}$ ). $\mathrm{The}$ mean $\pm \mathrm{SD}$ of $\mathrm{SE}$ was $-4.06 \pm 2.50 \mathrm{D}$, range $(-0.50$ to $-14.00 \mathrm{D})$. The mean $\pm \mathrm{SD}$ of CCT for the total hyperopic subjects was $530.8 \pm 37.2 \mu \mathrm{m}$, range (471 to $616 \mu \mathrm{m})$. The mean $\pm \mathrm{SD}$ of SE was $+3.57 \pm 1.98 \mathrm{D}$, range $(+0.50$ to $+8.50 \mathrm{D})$. About $16.2 \%$ of the myopic eyes and $12.7 \%$ of the hyperopic eyes have CCT less than $500 \mu \mathrm{m}$.

Conclusion: The mean of the central corneal thickness of the eastern Egyptian population was $532.8 \mu \mathrm{m}$ for myopic and $530.8 \mu \mathrm{m}$ for hyperopic subjects, respectively. The myopic and hyperopic subjects show a reduction in CCT with age. Females have a thinner cornea than males, $16.2 \%$ of the myopic eyes and $12.7 \%$ of the hyperopic eyes have CCT less than $500 \mu \mathrm{m}$.

Keywords: central corneal thickness, myopia, hyperopia, refractive errors

\section{Introduction}

Central corneal thickness (CCT) is a crucial indicator of a healthy cornea; it helps to evaluate corneal diseases. Average ordinary CCT is around $540 \mu \mathrm{m}$ most part, consists of the corneal stroma which is estimated to be $450 \mu \mathrm{m}$ in the centre. This stroma gives essential structural integrity and plays a significant function in keeping up corneal transparency. ${ }^{1}$

CCT usually is measured by ultrasonic pachymeter. ${ }^{2}$ It is an essential factor to assess the suitability in refractive surgeries as it is used to exclude patients at risk of postoperative corneal ectasia. ${ }^{3}$ It is also a measure of the rigidity of the cornea and
Correspondence: Amr A Gab-All

Suez Canal University, Faculty of

Medicine, Ophthalmology Department,

Ring Road, Ismailia, Egypt

Tel +20I22283626I

Email amrophth@hotmail.com 
has an influence on the precision of intraocular pressure (IOP) estimation by Goldman applanation tonometry (thick corneas offer resistance to it, causing a falsely higher IOP). ${ }^{4,5}$ Also, many studies have revealed that the differences in mean CCT and IOP among sub-groups may display the hypothesis of the presence of anatomical and morphological disparities among ethnicities. ${ }^{6,7}$

The increasing popularity of refractive surgeries brings significance to accurate and consistent data regarding the corneal thickness. ${ }^{8}$ Gathering this data from different population samples can aid the differentiation of healthy corneas from unhealthy corneas. ${ }^{9}$ The moment that normal range of the CCT is specified in a particular population, applicable studies can be done without the need for a control group. Moreover, patients' CCT records can be refereed with more dependability. ${ }^{10}$ The racial and environmental differences in corneal thickness makes it essential to get normative and reference data for each population to define this range. ${ }^{11,12}$

Current studies have showed that age, sex, race, and ethnicity may affect CCT. It is reported to be thinner in elders and African-Americans than in whites. ${ }^{8,13}$ Some studies showed that men had thicker corneas than women. ${ }^{14,15}$

In Egypt, there are few published articles that record $\mathrm{CCT}$ of the Egyptian population as a unique racial background and geographical location. So, this study aimed to give reference values of the CCT with different refractive errors for the adult eastern Egyptian population.

\section{Subjects and Methods}

All the subjects experienced comprehensive ocular examinations, including slit-lamp (Topcon, Tokyo, Japan) examination, IOP by Goldmann applanation tonometry (Shin-Nippon, Tokyo, Japan) direct and indirect ophthalmoscopy (Topcon, Tokyo, Japan), both cycloplegic (cyclopentolate HCL1\%, Plegica, Hikma pharmaceuticals) and subjective refractive error presented in spherical equivalent with auto-refractometer (Topcon KR 8900, Tokyo, Japan), keratometry and corneal topography by Sirius (CSO, Florence, Italy). Schirmer's testing (Hagg-Streit, Edinburgh, UK) without anaesthesia was used to exclude dry eyes.

Corneal thickness measurement was by ultrasonic pachymetry (Tomy, Tokyo, Japan). Five corneal thickness measurements were taken, and the average was used for analysis. All the measurement was between 9.00 and $10.00 \mathrm{am}$.
The eligibility criteria included myopia and hyperopia, a minimum age of 21 years, a regular corneal topography pattern, both sex and free of any existing systemic pathology. All female subjects were non-pregnant or breastfeeding. The exclusion criteria included subjects with a history of current or recent contact lens wear (not worn contact lenses two weeks before examination), ocular trauma, ocular surgeries, keratoconus, and glaucoma. None of the subjects was utilising any topical ophthalmic medications.

The subjects were divided ${ }^{16}$ into a broad range of myopia ( $\mathrm{SE} \leq-0.5 \mathrm{D})$ and hyperopia $(\mathrm{SE} \geq+0.5 \mathrm{D})$. Then, the myopic eyes divided into low ( $\mathrm{SE}>-3.0 \mathrm{D})$, moderate (SE-3.0 to $>-6.0 \mathrm{D})$, and high ( $\mathrm{SE} \leq-6 \mathrm{D})$. Similarly, the hyperopic eyes were divided into low $(\mathrm{SE}<+3.0 \mathrm{D})$ and moderate (SE+3.0D to $<+6.0 \mathrm{D})$ and high $(\geq+6.0 \mathrm{D})$.

This study follows the Declaration of Helsinki. It was reviewed and approved (approval No. 4182) by the research ethics committee of the Faculty of Medicine, Suez Canal University. No informed consent was required to review the medical records of the subjects due to the large number of the study sample and the retrospective nature of the study design. The confidentiality of the patients' data was guaranteed.

\section{Statistical Analysis}

All data manipulation and statistical analysis were performed by Statistical Package for the Social Sciences (SPSS version 25.0; IBM Corporation, Armonk, NY, USA). Baseline characteristics of the study population were presented as frequencies and percentages (\%) or mean values and standard deviations (SDs). Differences between frequencies in the groups were compared by Chisquare test. Kolmogorov-Smirnov test was used to test for data normality. Differences between means in the groups were compared by Student's $t$-test or Mann-Whitney test if data were not normal. To compare the difference in the mean measurements between the sub-groups of myopia and hyperopia, one-way ANOVA was performed, or Kruskal-Wallis tests if data were not normal. A P-value $<0.05$ was considered statistically significant.

\section{Results}

This study included 556 myopic subjects $(31.1 \%$ males and $68.9 \%$ females) and 610 hyperopic subjects $(34.4 \%$ males and $65.6 \%$ females) who came to private eye centre, Ismailia, Egypt for refractive surgery. Data included in the statistical analyses were obtained from a randomly selected eye of each subject (ie, each subject gave only one randomly selected eye), Table 1 . 
Table I General Characteristics of All Subjects

\begin{tabular}{|c|c|c|c|}
\hline Characteristics & $\begin{array}{l}\text { Myopic } \\
\text { Subjects }\end{array}$ & $\begin{array}{l}\text { Hyperopic } \\
\text { Subjects }\end{array}$ & $P$-value \\
\hline Eyes, $n$ & 556 & 610 & 一 \\
\hline \multicolumn{4}{|l|}{ Age (yrs): } \\
\hline Mean \pm SD & $27.3 \pm 7.0$ & $35.1 \pm 10.7$ & $<0.001 *$ \\
\hline Range & $(2 I-60)$ & $(21-60)$ & \\
\hline \multicolumn{4}{|l|}{ Age group (yrs), n (\%): } \\
\hline$<30$ & 390 (70.1\%) & $230(37.7 \%)$ & $<0.00 I^{*}$ \\
\hline $30-39$ & I34 (24.1\%) & $170(27.9 \%)$ & \\
\hline$\geq 40$ & $32(5.8 \%)$ & 210 (34.4\%) & \\
\hline \multicolumn{4}{|l|}{ Sex: } \\
\hline Male, n (\%) & 173 (31.1\%) & $210(34.4 \%)$ & $0.035 *$ \\
\hline Female, n (\%) & 383 (68.9\%) & $400(65.6 \%)$ & \\
\hline \multicolumn{4}{|l|}{ Laterality: } \\
\hline Right, n (\%) & $288(51.8 \%)$ & 300 (49.2\%) & $0.026^{*}$ \\
\hline Left, n (\%) & $268(48.2 \%)$ & 310 (50.8\%) & \\
\hline
\end{tabular}

Note: * Statistical significance ( $P$-value $<0.05)$.

Abbreviations: SD, standard deviation; $\mathrm{n}$, number; yrs, years.

\section{Myopic Subjects}

Mean \pm SD of CCT for the total myopic subjects was 532.8 $\pm 32.6 \mu \mathrm{m}$ range (470 to $627 \mu \mathrm{m})$. Mean $\pm \mathrm{SD}$ of spherical equivalent (SE) was $-4.06 \pm 2.5 \mathrm{D}$ range $(-0.50$ to- $14.00 \mathrm{D})$.
The subjects with $\mathrm{CCT}<500 \mu \mathrm{m}$ were $16.2 \%$ of the total myopic subjects. The mean $\pm \mathrm{SD}$ of the CCT, according to the different age groups, eye laterality, and sex, are presented in Table 2. When further sub-classified the myopic subjects, those with low myopia $>-3.0 \mathrm{D}$ the mean \pm SD of the CCT was532.7 $\pm 33.5 \mu \mathrm{m}$, range (470 to $615 \mu \mathrm{m})$. Moderate myopia -3.0 to $>-6.0 \mathrm{D}$ the mean $\pm \mathrm{SD}$ of the CCT was $532.8 \pm 31.81 \mu \mathrm{m}$, range (471 to $627 \mu \mathrm{m}$ ). Those with high myopia $\leq-6.0 \mathrm{D}$ the mean \pm SD of the CCT was $533.2 \pm 31.83 \mu \mathrm{m}$, range (472 to $610 \mu \mathrm{m})$. There were no statistically significant differences between myopic subgroups regarding $\mathrm{CCT}(\mathrm{P}=0.897)$. Table 2 , Figure 1 . The range of distribution of the CCT in myopic adult Egyptian subjects is presented in Figure 2.

\section{Hyperopic Subjects}

Mean \pm SD of CCT for the total hyperopic subjects was 530.8 $\pm 37.2 \mu \mathrm{m}$ range ( 471 to $616 \mu \mathrm{m})$. Mean $\pm \mathrm{SD}$ of the refraction error was $+3.57 \pm 1.98 \mathrm{D}$ range $(+0.50$ to $+8.5 \mathrm{D})$. The subjects with $\mathrm{CCT}<500 \mu \mathrm{m}$ were $12.7 \%$ of the total hyperopic subjects. The mean $\pm \mathrm{SD}$ of the CCT, according to the different age groups, eye laterality, and sex, are presented in Table 3. When further sub-classified the hyperopic subjects, those with low hyperopia $<+3.0 \mathrm{D}$ the mean $\pm \mathrm{SD}$ of the CCT was

Table 2 General Characteristics of Myopia Sub-Groups

\begin{tabular}{|c|c|c|c|c|c|}
\hline & \multirow[t]{2}{*}{ Myopia Total Subjects } & \multicolumn{3}{|c|}{ Myopia Sub-Groups n (Column \%) } & \multirow[t]{2}{*}{ P-value } \\
\hline & & Low >-3.0D & Moderate -3.0 to $>-6.0 \mathrm{D}$ & High $\leq-6.0 \mathrm{D}$ & \\
\hline Number (\%) & $556(100 \%)$ & $263(47.3 \%)$ & $207(37.2 \%)$ & $86(15.5 \%)$ & - \\
\hline $\begin{array}{l}\text { Age }(\mathbf{y r s}): \\
\text { Mean } \pm S D \\
\text { Range }\end{array}$ & $\begin{array}{l}27.3 \pm 7.0 \\
(21-60)\end{array}$ & $\begin{array}{l}27.5 \pm 6.3 \\
(21 \text { to } 60)\end{array}$ & $\begin{array}{l}27.1 \pm 7.1 \\
(21 \text { to } 60)\end{array}$ & $\begin{array}{l}27.3 \pm 8.7 \\
(21 \text { to } 60)\end{array}$ & 0.106 \\
\hline $\begin{array}{l}\text { Sex, n (\%): } \\
\quad \text { Male } \\
\text { Female }\end{array}$ & $\begin{array}{l}173(31.1 \%) \\
383(68.9 \%)\end{array}$ & $\begin{array}{l}99(37.6 \%) \\
164(62.4 \%)\end{array}$ & $\begin{array}{l}53(25.6 \%) \\
154(74.4 \%)\end{array}$ & $\begin{array}{l}21(24.4 \%) \\
65(75.6 \%)\end{array}$ & $0.007^{*}$ \\
\hline $\begin{array}{l}\text { Eye, n (\%): } \\
\quad \text { Right } \\
\text { Left }\end{array}$ & $\begin{array}{l}288(51.8 \%) \\
268(48.2 \%)\end{array}$ & $\begin{array}{l}\text { I } 40 \text { (53.2\%) } \\
123(46.8 \%)\end{array}$ & $\begin{array}{l}100(48.3 \%) \\
107(51.7 \%)\end{array}$ & $\begin{array}{l}48(55.8 \%) \\
38(44.2 \%)\end{array}$ & 0.410 \\
\hline $\begin{array}{l}\text { SE (D): } \\
\quad \text { Mean } \pm S D \\
\text { Range }\end{array}$ & $\begin{array}{l}-4.06 \pm 2.50 \\
(-0.50 \text { to }-14.00)\end{array}$ & $\begin{array}{l}-2.14 \pm 0.77 \\
(-0.50 \text { to }-4.75)\end{array}$ & $\begin{array}{l}-4.62 \pm 1.05 \\
(-3.0 \text { to }-8.50)\end{array}$ & $\begin{array}{l}-8.62 \pm 1.76 \\
(-6.0 \text { to }-14.25)\end{array}$ & $<0.00 I^{*}$ \\
\hline $\begin{array}{l}\text { CCT }(\mu \mathrm{m}): \\
\text { Mean } \pm \text { SD } \\
\text { Range }\end{array}$ & $\begin{array}{l}532.8 \pm 32.6 \\
(470 \text { to } 627)\end{array}$ & $\begin{array}{l}532.7 \pm 33.5 \\
(470 \text { to } 615)\end{array}$ & $\begin{array}{l}532.8 \pm 31.8 I \\
(47 \mid \text { to } 627)\end{array}$ & $\begin{array}{l}533.2 \pm 31.83 \\
(472 \text { to } 610)\end{array}$ & 0.897 \\
\hline
\end{tabular}

Note: * Statistically significant (P-value $<0.05)$.

Abbreviations: SE, spherical equivalent; $n$, number; yrs, years; $\mu \mathrm{m}$, micrometre; SD, standard deviation; $D$, dioptre. 


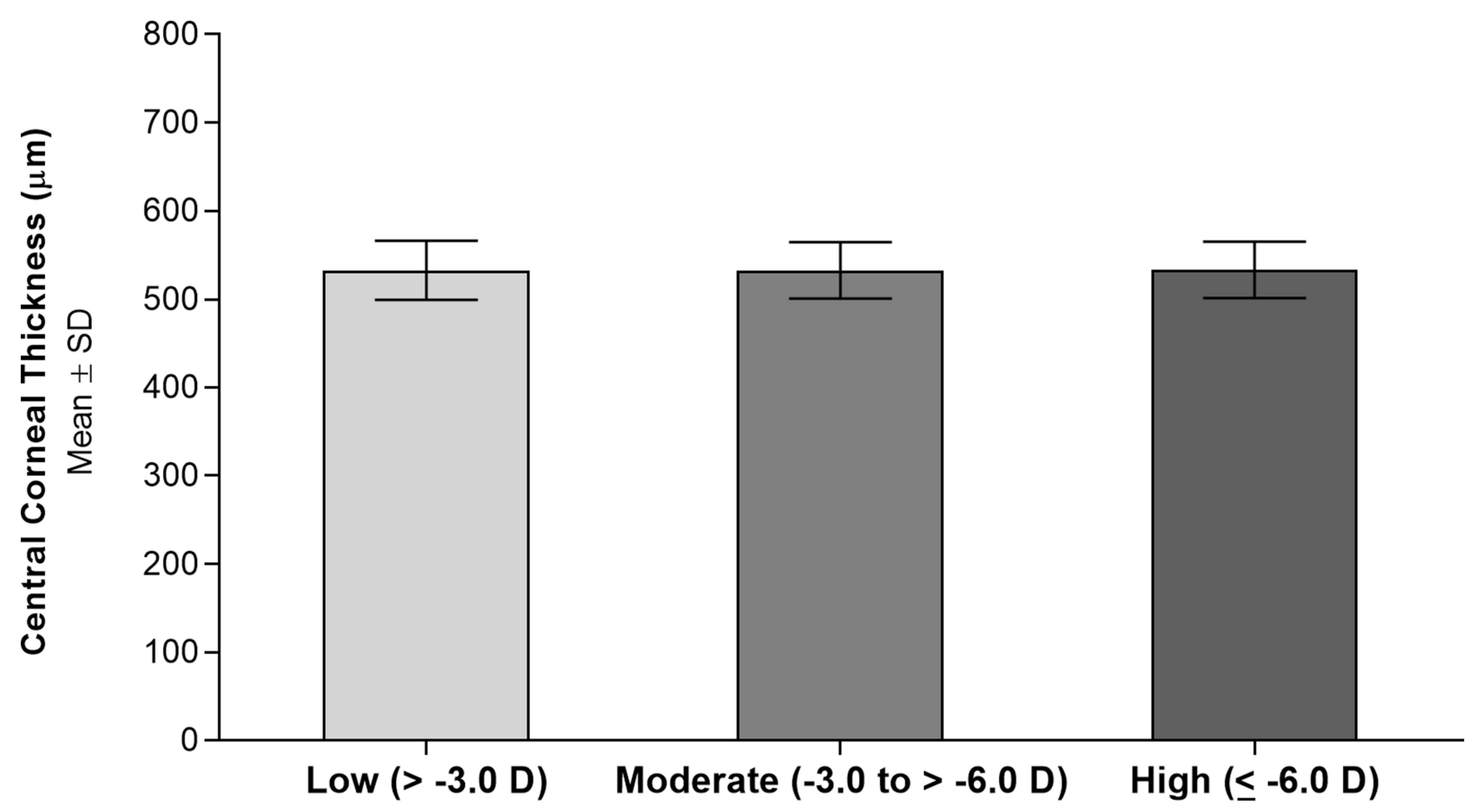

\section{Myopia sub-groups}

Figure I Meantstandard deviation (SD) of the central corneal thickness of myopia sub-groups.

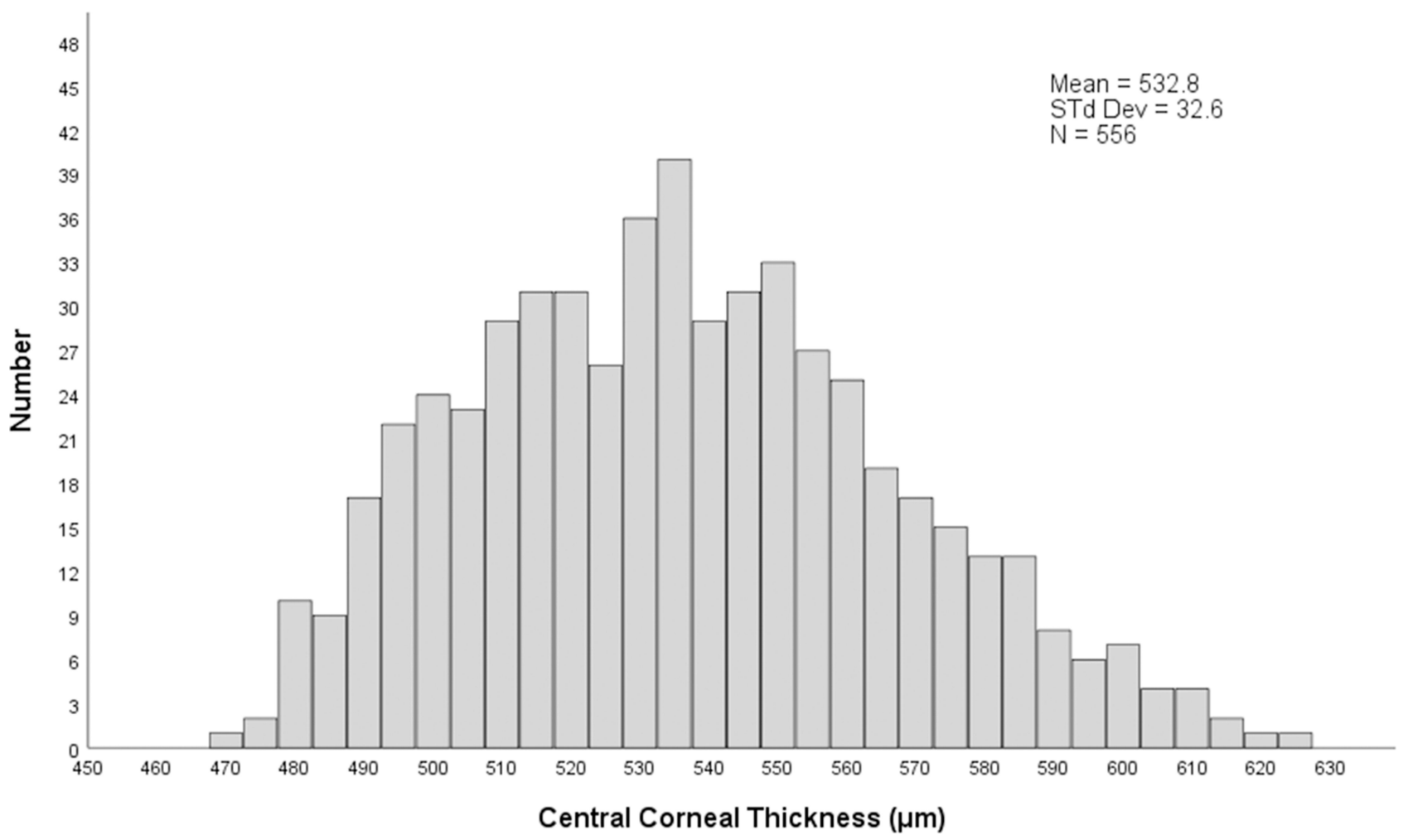

Figure 2 Histogram showing the distribution of central corneal thickness values in myopic adult Egyptian subjects (Std. Dev. = Standard Deviation). 
Table 3 General Characteristics of Hyperopia Sub-Groups

\begin{tabular}{|c|c|c|c|c|c|}
\hline & \multirow[t]{2}{*}{ Hyperopia Total Subjects } & \multicolumn{3}{|c|}{ Hyperopia Sub-Groups n (Column \%) } & \multirow[t]{2}{*}{ P-value } \\
\hline & & Low $<+3.0 \mathrm{D}$ & Moderate +3.0 to $<+6.0 \mathrm{D}$ & High $\geq+6.0 \mathrm{D}$ & \\
\hline Number (\%) & $610(100 \%)$ & $290(47.5 \%)$ & $190(31.1 \%)$ & $130(2 \mid .3 \%)$ & - \\
\hline $\begin{array}{l}\text { Age (yrs): } \\
\text { Mean } \pm S D \\
\text { Range }\end{array}$ & $\begin{array}{l}35.1 \pm 10.7 \\
(21 \text { to } 60)\end{array}$ & $\begin{array}{l}35.5 \pm 10.6 \\
(21 \text { to } 60)\end{array}$ & $\begin{array}{l}39.0 \pm 11.5 \\
(21 \text { to } 54)\end{array}$ & $\begin{array}{l}28.6 \pm 6.1 \\
(21 \text { to } 42)\end{array}$ & $0.022^{*}$ \\
\hline $\begin{array}{l}\text { Sex, } \mathbf{n}(\%): \\
\quad \text { Male } \\
\text { Female }\end{array}$ & $\begin{array}{l}210(34.4 \%) \\
400(65.6 \%)\end{array}$ & $\begin{array}{l}100(34.5 \%) \\
190(65.5 \%)\end{array}$ & $\begin{array}{l}60(31.6 \%) \\
130(68.4 \%)\end{array}$ & $\begin{array}{l}50(38.5 \%) \\
80(61.5 \%)\end{array}$ & 0.922 \\
\hline $\begin{array}{l}\text { Eye, n (\%): } \\
\text { Right } \\
\text { Left }\end{array}$ & $\begin{array}{l}300(49.2 \%) \\
310(50.8 \%)\end{array}$ & $\begin{array}{l}90(31.0 \%) \\
200(69.0 \%)\end{array}$ & $\begin{array}{l}120(63.2 \%) \\
70(36.8 \%)\end{array}$ & $\begin{array}{l}90(69.2 \%) \\
40(30.8 \%)\end{array}$ & $0.025^{*}$ \\
\hline $\begin{array}{l}\text { SE(D): } \\
\quad \text { Mean } \pm S D \\
\text { Range }\end{array}$ & $\begin{array}{l}+3.57 \pm 1.98 \\
(+0.50 \text { to }+8.50)\end{array}$ & $\begin{array}{l}+1.85 \pm 0.6 \mathrm{I} \\
(+0.5 \text { to }+2.75)\end{array}$ & $\begin{array}{l}+4.14 \pm 0.60 \\
(+3.0 \text { to }+5.25)\end{array}$ & $\begin{array}{l}+6.58 \pm 0.82 \\
(+6.0 \text { to }+8.50)\end{array}$ & $<0.00$ I* \\
\hline $\begin{array}{l}\text { CCT }(\mu \mathrm{m}): \\
\text { Mean } \pm S D \\
\text { Range }\end{array}$ & $\begin{array}{l}530.8 \pm 37.2 \\
(47 \mid \text { to } 616)\end{array}$ & $\begin{array}{l}527.5 \pm 38.0 \\
(471 \text { to } 616)\end{array}$ & $\begin{array}{l}524.7 \pm 36.3 \\
(478 \text { to } 588)\end{array}$ & $\begin{array}{l}547.2 \pm 34.7 \\
(491 \text { to } 606)\end{array}$ & 0.197 \\
\hline
\end{tabular}

Note: *Statistically significant ( $\mathrm{P}$-value $<0.05)$.

Abbreviations: SE, spherical equivalent; $n$, number; yrs, years; $\mu \mathrm{m}$, micrometre; SD, standard deviation; $D$, dioptre.

$527.5 \pm 38.0 \mu \mathrm{m}$, range (471 to $616 \mu \mathrm{m})$. Moderate hyperopia +3.0 to $<+6.0 \mathrm{D}$ the mean $\pm \mathrm{SD}$ of the CCT was $524.7 \pm 36.3 \mu \mathrm{m}$, range (478 to $588 \mu \mathrm{m})$. Those with high hyperopia $\geq+6.0 \mathrm{D}$ the mean \pm SD of the CCT was $547.2 \pm 34.7 \mu \mathrm{m}$, range (491 to $606 \mu \mathrm{m})$. There are also no statistical significance differences between hyperopic sub-groups as regarding CCT $(\mathrm{P}=0.197)$, Table 3, Figure 3. The range of distribution of the CCT in hyperopic adult Egyptian subjects is presented in Figure 4.

\section{Age, Sex, and Eye Laterality}

The subjects were divided into three age subgroups $<30$ years, 30 to 39 years, and $\geq 40$ years. The mean \pm SD of CCT of these sub-groups found to be thinner with age, but the differences were statistically not significant in both myopic subjects $(\mathrm{P} 2=0.430)$ and hyperopic subjects $(\mathrm{P} 2=0.898)$. Male has thicker cornea than females with statistically insignificant differences $(\mathrm{P} 4=0.473$ and $\mathrm{P}=0.395$ ) for the myopic and hyperopic subjects, respectively Table 4.

\section{Discussion}

Reference values are a significant base for clinical decisions during patient examinations and diagnosis of different ocular diseases. The diagnostic criteria for those diseases depended on the differences between those reference values and clinical observations. ${ }^{6}$ Reference values for CCT in the eastern Egyptian population with myopia and hyperopia were measured, quantified, and presented in this study. These values offer tools for interpreting many clinical situations and evaluating changes in physiology and corneal biology in response to systemic diseases among the Egyptians. This also will help for accurate diagnoses of suspected keratoconus, early keratoconus, and other corneal diseases. The mean reference values for the CCT of the eastern Egyptian population aged from 21 to 60 years with different refractive errors measured by ultrasonic pachymetry were $532.8 \mu \mathrm{m}$ for myopic and $530.8 \mu \mathrm{m}$ for hyperopic subjects, respectively. These values are relatively higher compared to that recorded in other studies (other ethnic groups). ${ }^{6,16-20}$ Values of the CCT of different ethnical groups vary and are summarised in Table 5. Also, it reports that myopic and hyperopic subjects show a statistically non-significant reduction in CCT with ageing, females have thinner corneas than males, with no significant differences as recorded in other studies. ${ }^{18,21,22}$ Also, about $16.2 \%$ of the myopic eyes and $12.7 \%$ of the hyperopic eyes (in the investigated sample) have CCT less than $500 \mu \mathrm{m}$, and this 


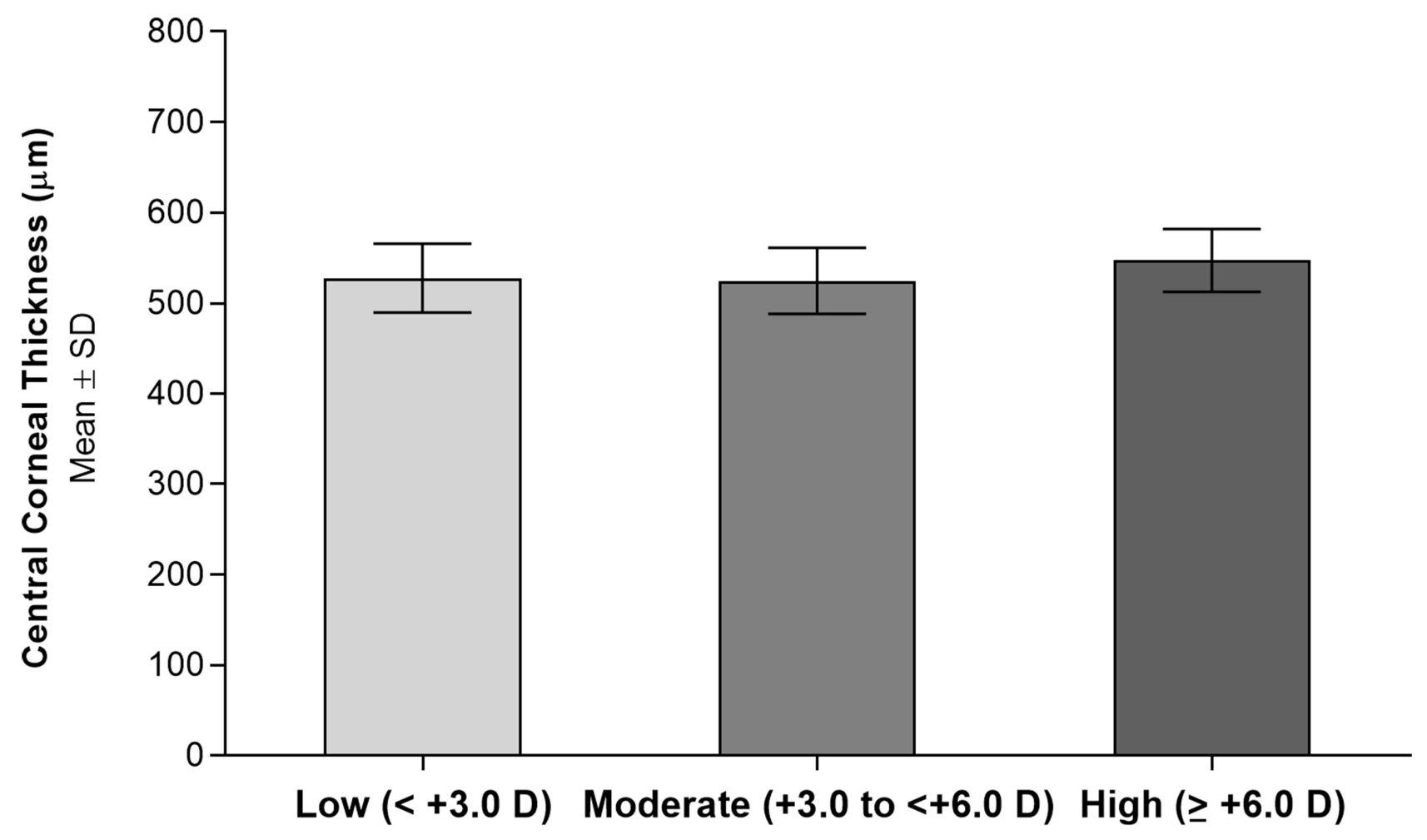

Hyperopia Sub-groups

Figure 3 Mean \pm standard deviation (SD) of the central corneal thickness of hyperopia sub-groups.

means that those patients are not suitable for LASIK. A remarkable previous study by Mostafa $^{23}$ recorded mean CCT in a southern Egyptian population by ultrasonic pachymetry in emmetropic, myopic, and hyperopic subjects aged from 16 to70 years. The recorded mean CCT was $532.6 \mu \mathrm{m}$ in emmetropic, $531.5 \mu \mathrm{m}$ in myopic $<6.0 \mathrm{D}, 531.1 \mu \mathrm{m}$ in myopic $>6.0 \mathrm{D}$ and $533 \mu \mathrm{m}$ in hyperopic. The percentage of patients with a CCT $\leq 500 \mu \mathrm{m}$ was $31.9 \%$ in the emmetropic, $37.9 \%$ in myopic and $22.9 \%$ in hyperopic subjects.

Normal reference values represent an essential base of clinical judgment for the patients. Once the normal range of CCT is specified in a population, applicable studies can be completed without the necessity for a control group, and patients' pachymetry analyses can be adjudicated with more certainty. ${ }^{36-39}$

Still, most ophthalmic diagnostic instruments produced in America and Europe use normal reference values of their populations. In this manner, it may not be useful to assess the Egyptian population utilising normal values from Americans and Europeans. Gathering reference values of the corneal thickness in a large population of adult Egyptians will help in precise diagnoses of keratoconus and keratoconus suspect, besides other corneal diseases, where these reference values of Egyptians CCT are essential also in glaucoma diagnosis and treatment.

Principally in successful corneal refractive surgery, corneal thickness is an essential factor for the preoperative screening of keratoconus and for pre-surgical assessment of the precise ablation profile to maintain post-surgical corneal stability. This reduces the incidence of postLASIK corneal ectasia. ${ }^{40}$

Increased care on the corneal thickness has brought about its description in a considerable number of studies from different regions and countries..$^{21-23,36-48}$ For the contrasts in ethnicity, geography, and other environmental variables, there is a wide-extending variety within these records; in this way, reference values of the corneal thickness-related parameters should not be utilised imprecisely and should be sensitive to variations within each population.

Some limitations should be considered while reading this study. First, it is a retrospective study, and in this way, all related restrictions must be thought of. Second, factors affecting female central corneal thickness, like the menstrual cycle, 


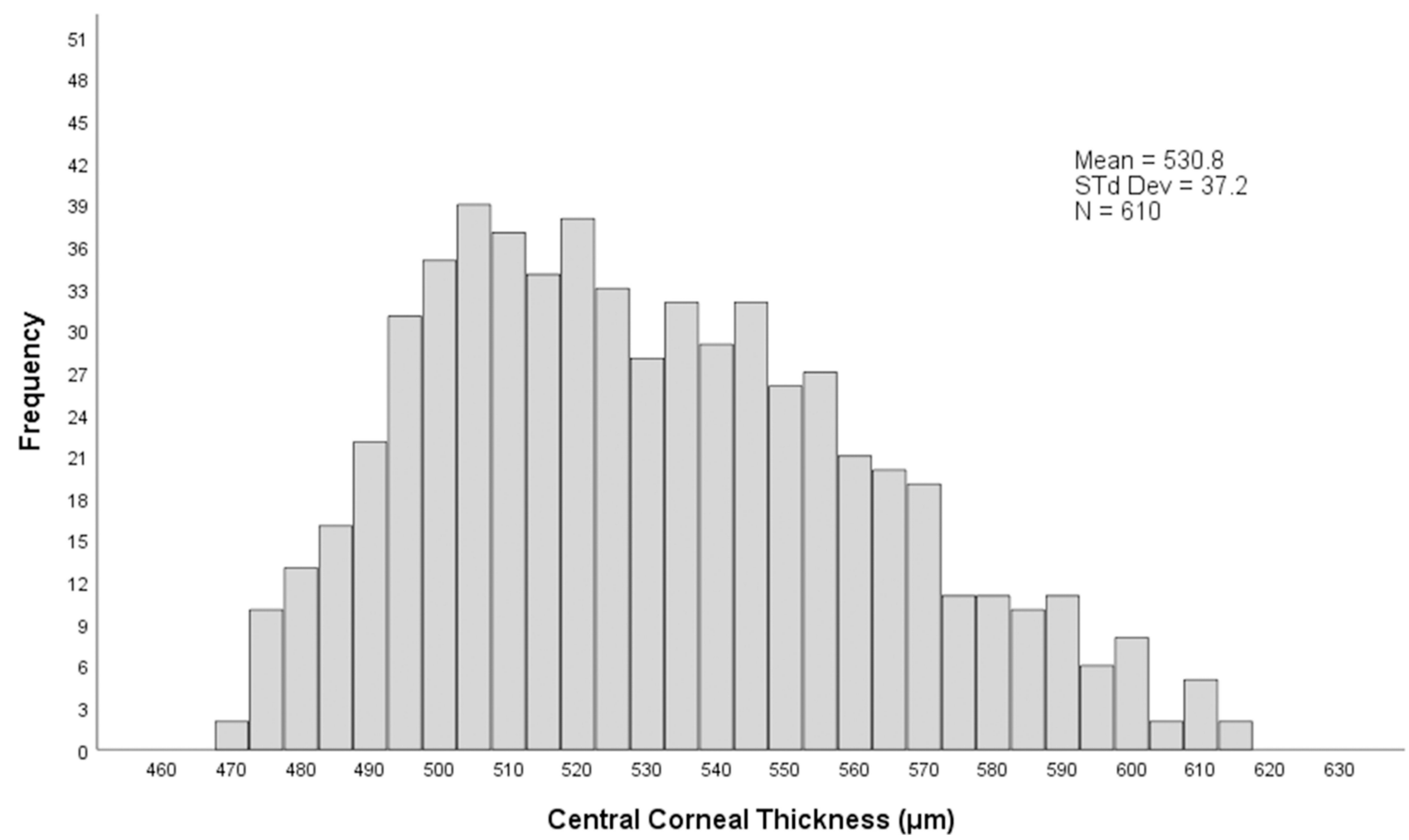

Figure 4 Histogram showing the distribution of central corneal thickness values in hyperopic adult Egyptian subjects (Std. Dev. = Standard Deviation).

lactation, oral contraceptive pills, and hormonal therapy, were not associated. Third, although ultrasonic pachymetry is considered the gold standard for the measurement of CCT, it is operator dependent and can modify its results if the cornea is indented during the measurement or non- perpendicular alignment of the ultrasound probe. Fourth, the unequal distribution of age groups between the myopic and hyperopic subjects.

In conclusion, the mean of the CCT of the eastern Egyptian population was $532.8 \mu \mathrm{m}$ for myopic and $530.8 \mu \mathrm{m}$

Table 4 Central Corneal Thickness by Age Groups, Eye Laterality and Sex in Myopic and Hyperopic Subjects

\begin{tabular}{|c|c|c|c|c|}
\hline & & \multicolumn{2}{|c|}{ Central Corneal Thickness Mean士SD Range } & \multirow[t]{2}{*}{$P I$-value } \\
\hline & & Myopia & Hyperopia & \\
\hline \multirow[t]{4}{*}{ Age groups (yrs): } & $<30$ & $\begin{array}{l}539.5 \pm 34.7 \\
(477 \text { to } 617)\end{array}$ & $\begin{array}{l}535.7 \pm 41.5 \\
(473 \text { to } 616)\end{array}$ & 0.092 \\
\hline & $30-39$ & $\begin{array}{l}533.7 \pm 31.8 \\
(471 \text { to } 621)\end{array}$ & $\begin{array}{l}532.1 \pm 29.4 \\
(495 \text { to } 591)\end{array}$ & 0.372 \\
\hline & $\geq \mathbf{4 0}$ & $\begin{array}{l}532.0 \pm 32.6 \\
(470 \text { to } 627)\end{array}$ & $\begin{array}{l}524.4 \pm 38.7 \\
(47 \mid \text { to } 589)\end{array}$ & $0.0003 *$ \\
\hline & P2-Value & 0.430 & 0.898 & \\
\hline \multirow[t]{2}{*}{ Sex } & Male & $\begin{array}{l}534.3 \pm 31.8 \\
(47 \mid \text { to } 615)\end{array}$ & $\begin{array}{l}536.5 \pm 36.6 \\
(478 \text { to } 606)\end{array}$ & 0.276 \\
\hline & $\begin{array}{l}\text { Female } \\
\text { P3-value }\end{array}$ & $\begin{array}{l}532.2 \pm 32.9 \\
(470 \text { to } 627) \\
0.473\end{array}$ & $\begin{array}{l}527.9 \pm 37.7 \\
(471 \text { to } 616) \\
0.395\end{array}$ & $0.039^{*}$ \\
\hline
\end{tabular}

Note: *Statistically significant ( $\mathrm{P}$-value $<0.05)$.

Abbreviations: SD, standard deviation; yrs, years. 
Table 5 Summary of Mean Central Corneal Thickness in Different Ethnic Groups

\begin{tabular}{|c|c|c|c|c|}
\hline Ethnic Groups & Age Group (yrs) & CCT $(\mu \mathrm{m})$ & Measured by & Study Type \\
\hline Australian ${ }^{19}$ & $|4-5|$ & 508 & Ultrasound & Case-control \\
\hline Japanese ${ }^{24}$ & $40-80$ & $5 \mid 4.5$ & Specular microscope & Cross-sectional \\
\hline Japanese ${ }^{18}$ & $\leq 40$ & 517.5 & Specular microscope & Cross-sectional \\
\hline African American ${ }^{25}$ & $67.3 \pm 15.9 *$ & 521.0 & Ultrasound & Retrospective \\
\hline Ghana $^{26}$ & $40-98$ & 525.3 & Ultrasound & Prospective \\
\hline Reykjavik $^{27}$ & $<50$ & 527.0 & Scheimpflug anterior segment photography & Cross-sectional \\
\hline European $^{28}$ & $5-15$ & 529.0 & Ultrasound & Cross-sectional \\
\hline European ${ }^{28}$ & $32-60$ & 533.0 & Ultrasound & Clinical \\
\hline Thai $^{29}$ & $12-60$ & 535.2 & Ultrasound & NA \\
\hline Australian 19 & $15-56$ & 541 & Ultrasound & Case-control \\
\hline Singapore ${ }^{30}$ & $40-80$ & 541.2 & Ultrasound & Cross-sectional \\
\hline Bridlington $^{31}$ & $<65$ & 544.1 & Ultrasound & Population screened \\
\hline South Australia ${ }^{32}$ & $44.8 \pm 14.5^{*}$ & 544.6 & Ultrasound & Cross-sectional \\
\hline Latinos $^{33}$ & 40 & 546.9 & Ultrasound & Population-based cohort \\
\hline Hispanic $^{25}$ & $67.3 \pm 15.9 *$ & 548.1 & Ultrasound & Retrospective \\
\hline Filipino 25 & $67.3 \pm 15.9 *$ & 550.6 & Ultrasound & Retrospective \\
\hline Turkish ${ }^{34}$ & $6-88$ & 552.2 & NA & Clinical \\
\hline Chinese $^{25}$ & $67.3 \pm 15.9^{*}$ & 555.6 & Ultrasound & Retrospective \\
\hline Iranian ${ }^{42}$ & $|4-8|$ & 555.6 & Orbscan & Cross-sectional \\
\hline Beijing $^{35}$ & $<45$ & 556.2 & Ultrasound & Cross-sectional \\
\hline German $^{41}$ & $60.2 \pm 15.0^{*}$ & 616.6 & NA & Histomorphometric \\
\hline
\end{tabular}

Note: *mean $\pm S D$.

Abbreviations: NA, not applicable; yrs, years; $\mu \mathrm{m}$, micrometre.

for hyperopic subjects, respectively. The myopic and hyperopic subjects show a reduction in CCT with age. Females have a thinner cornea than males, $16.2 \%$ of the myopic eyes and $12.7 \%$ of the hyperopic eyes have CCT less than $500 \mu \mathrm{m}$.

\section{Funding}

There is no funding to report.

\section{Disclosure}

The author reports no conflicts of interest in this work.

\section{References}

1. Lee J-H, Kim JH, Kim SW. Repeatability of central corneal thickness measurement using rotating Scheimpflug camera in dry and normal eyes. Eye Contact Lens. 2018;44(11):S29-S32. doi:10.1097/ICL.00 00000000000373

2. Pakravan M, Javadi MA, Yazdani S, et al. Distribution of intraocular pressure, central corneal thickness and vertical cup-to-disc ratio in a healthy Iranian population: the Yazd Eye Study. Acta Ophthalmol. 2017;95(2):e144-e151. doi:10.1111/aos.13231

3. Kim BK, Mun SJ, Yang YH, Kim JS, Moon JH, Chung YT. Comparison of anterior segment changes after femtosecond laser LASIK and SMILE using a dual rotating Scheimpflug analyzer. BMC Ophthalmology. 2019;19(1):251. doi:10.1186/s12886-019-1257-0

4. Realini T, Gurka MJ, Weinreb RN. Reproducibility of central corneal thickness measurements in healthy and glaucomatous eyes. J Glaucoma. 2017;26(9):787-791. doi:10.1097/JG.0000000000000738
5. Agarwal L, Agrawal N, Badhu BP, Lavaju P. Central corneal thickness and intraocular pressure in patients of primary open angle glaucoma and normal population in Nepalese population: A hospital based study. Nepalese Journal of Ophthalmology. 2019;11(1):46-54. doi:10.3126/nepjoph.v11i1.25418

6. Doughty MJ, Zaman ML. Human corneal thickness and its impact on intraocular pressure measures: a review and meta-analysis approach. Surv Ophthalmol. 2000;44(5):367-408. doi:10.1016/S0039-6257(00)00110-7

7. Farvardin M, Heidary F, Sayehmiri K, Gharebaghi R, Jabbarvand Behrooz M, Comprehensive A. Meta-analysis on Intra Ocular Pressure and Central Corneal Thickness in Healthy Children. Iran J Public Health. 2017;46(6):724-732.

8. Wang Q, Liu W, Wu Y, Ma Y, Zhao G. Central corneal thickness and its relationship to ocular parameters in young adult myopic eyes. Clin Exp Optom. 2017;100(3):250-254. doi:10.1111/cxo.12485

9. Gonz??lez-M??ijome JM, Sa??udo-Buitrago F, L??pez-Alemany A, Almeida JB, Parafita MA. Correlations between central and peripheral changes in anterior corneal topography after myopic LASIK and their implications in postsurgical contact lens fitting. Eye Contact Lens. 2006;32(4):197-202. doi:10.1097/01.icl.0000191951.89321.b6

10. Prasad A, Fry K, Hersh PS. Relationship of age and refraction to central corneal thickness. Cornea. 2011;30(5):553-555. doi:10.1097/ ICO.0b013e3181fb880c

11. Mercieca K, Odogu V, Fiebai B, Arowolo O, Chukwuka F. Comparing central corneal thickness in a sub-Saharan cohort to African Americans and Afro-Caribbeans. Cornea. 2007;26 (5):557-560. doi:10.1097/ICO.0b013e3180415d90

12. Tayyab A, Masrur A, Afzal F, Iqbal F, Naseem K. Central corneal thickness and its relationship to intra-ocular and epidemiological determinants. J Coll Physicians Surg Pak. 2016;26(6):494-497.

13. Baboolal SO, Smit DP. South African Eye Study (SAES): ethnic differences in central corneal thickness and intraocular pressure. Eye. 2018;32(4):749-756. doi:10.1038/eye.2017.291 
14. Hoffmann EM, Lamparter J, Mirshahi A, et al. Distribution of central corneal thickness and its association with ocular parameters in a large central European cohort: the Gutenberg health study. PLoS One. 2013;8(8):e66158. doi:10.1371/journal.pone.0066158

15. Badr M, Masis Solano M, Amoozgar B, Nguyen A, Porco T, Lin S. Central Corneal Thickness Variances Among Different Asian Ethnicities in Glaucoma and Nonglaucoma Patients. J Glaucoma. 2019;28(3):223-230. doi:10.1097/IJG.0000000000001180

16. Hashmani N, Hashmani S, Hanfi AN, et al. Effect of age, sex, and refractive errors on central corneal thickness measured by Oculus Pentacam $^{\circledR}$. Clin Ophthalmol. 2017;11:1233-1238. doi:10.2147/ OPTH.S141313

17. Eysteinsson T, Jonasson F, Sasaki H, et al. Central corneal thickness, radius of the corneal curvature and intraocular pressure in normal subjects using non-contact techniques: reykjavik Eye Study. Acta Ophthalmol Scand. 2002;80(1):11-15.

18. Suzuki S, Suzuki Y, Iwase A, Araie M. Corneal thickness in an ophthalmologically normal Japanese population. Ophthalmology. 2005;112(8):1327-1336. doi:10.1016/j.ophtha.2005.03.022

19. Landers JA, Billing KJ, Mills RA, et al. Central corneal thickness of indigenous Australians within Central Australia. Am J Ophthalmol. 2007;143(2):360-362. doi:10.1016/j.ajo.2006.09.047

20. Gros-Otero J, Arruabarrena-Sanchez C, Teus M. Espesor corneal central en una población sana española. Arch Soc Esp Oftalmol. 2011;86(3):73-76. doi:10.1016/j.oftal.2010.12.008

21. Rocha KM, Perez-Straziota CE, Stulting RD, Randleman JBSD-OCT. SD-OCT Analysis of Regional Epithelial Thickness Profiles in Keratoconus, Postoperative Corneal Ectasia, and Normal Eyes. J Refract Surg. 2013;29(3):173-179. doi:10.3928/1081597X-20130129-08

22. Jiang J, Ong K. Variability of Central Corneal Thickness Measurements - Comparing Zeiss IOL Master and Tomey Corneal Specular Microscope. Asia Pac J Ophthalmol. 2019;8(4):275-279. doi:10.1097/APO.0000000000000243

23. Mostafa EM. Central corneal thickness in southern Egypt. Int Ophthalmol. 2014;34(4):809-815. doi:10.1007/s10792-0139885-5

24. Nomura H, Ando F, Niino N, Shimokata H, Miyake Y. The relationship between age and intraocular pressure in a Japanese population: the influence of central corneal thickness. Curr Eye Res. 2002;24 (2):81-85. doi:10.1076/ceyr.24.2.81.8161

25. Aghaian E, Choe JE, Lin S, Stamper RL. Central corneal thickness of Caucasians, Chinese, Hispanics, Filipinos, African Americans, and Japanese in a glaucoma clinic. Ophthalmology. 2004;111 (12):2211-2219. doi:10.1016/j.ophtha.2004.06.013

26. Kim HY, Budenz DL, Lee PS, Feuer WJ, Barton K. Comparison of central corneal thickness using anterior segment optical coherence tomography vs ultrasound pachymetry. Am J Ophthalmol. 2008;145 (2):228-232. doi:10.1016/j.ajo.2007.09.030

27. Eysteinsson T, Jonasson F, Sasaki H, et al. Reykjavik Eye Study Group. Central corneal thickness, radius of the corneal curvature and intraocular pressure in normal subjects using non-contact techniques: reykjavik Eye Study. Acta Ophthalmol Scand. 2002;80 (1):11-15. doi:10.1034/j.1600-0420.2002.800103.x

28. Doughty MJ, Laiquzzaman M, Muller A, Oblak E, Button NF. Central corneal thickness in European (white) individuals, especially children and the elderly, and assessment of its possible importance in clinical measures of intra-ocular pressure. Ophthalmic Physiol Opt. 2002;22(6):491-504. doi:10.1046/j.1475-1313.2002.00053.x

29. Lekskul M, Aimpun P, Nawanopparatskul B, et al. The correlations between central corneal thickness and age, gender, intraocular pressure and refractive error of aged 12-60 years old in rural Thai community. J Med Assoc Thai. 2005;88(Suppl 3):S175-S179.

30. Su DHW, Wong TY, Wong W-L, et al. Singapore Malay Eye Study Group. Diabetes, hyperglycemia, and central corneal thickness: the Singapore Malay Eye Study. Ophthalmology. 2008;115(6):964-968. doi:10.1016/j.ophtha.2007.08.021
31. Hawker MJ, Edmunds MR, Vernon SA, Hillman JG, MacNab HK. The relationship between central corneal thickness and the optic disc in an elderly population: the Bridlington Eye Assessment Project. Eye. 2009;23(1):56-62.Eye. doi:10.1038/sj.eye.6703001

32. Durkin SR, Tan EW, Casson RJ, Selva D, Newland HS. Central corneal thickness among Aboriginal people attending eye clinics in remote South Australia. Clin Experiment Ophthalmol. 2007;35 (8):728-732. doi:10.1111/j.1442-9071.2007.01574.x

33. Hahn S, Azen S, Ying-Lai M, Varma R. Los Angeles Latino Eye Study Group. Central corneal thickness in Latinos. Invest Ophthalmol Vis Sci. 2003;44(4):1508-1512. doi:10.1167/iovs.02-0641

34. Altinok A, Sen E, Yazici A, Aksakal FN, Oncul H, Koklu G. Factors influencing central corneal thickness in a Turkish population. Curr Eye Res. 2007;32(5):413-419. doi:10.1080/02713680701344361

35. Zhang H, Xu L, Chen C, Jonas JB. Central corneal thickness in adult Chinese. Association with ocular and general parameters. The Beijing Eye Study. Graefes Arch Clin Exp Ophthalmol. 2008;246 (4):587-592. doi:10.1007/s00417-007-0760-9

36. Cho Y, Hieda O, Wakimasu K, et al. Multiple linear regression analysis of the impact of corneal epithelial thickness on refractive error Post corneal refractive surgery. Am J Ophthalmol. 2019;207:326-332. doi:10.1016/j.ajo.2019.05.016

37. Abah ER, Mahmud-Ajeigbe AF, Sharief S, Chinda D, Jiya PY, BobEgbe O. Central corneal thickness and intraocular pressure of adult Nigerians: an assessment of Zaria community. West Afr J Med. 2018;35(3):158-161.

38. Mansoori T, Balakrishna N. Repeatability and agreement of central corneal thickness measurement with non-contact methods: a comparative study. Int Ophthalmol. 2018;38(3):959-966. doi:10.1007/s10792-017-0543-1

39. Sedaghat M-R, Momeni-Moghaddam H, Gazanchian M, et al. Corneal epithelial thickness mapping after photorefractive keratectomy for myopia. J Refract Surg. 2019;35(10):632-641. doi:10.3928/ 1081597X-20190826-03

40. Carbonaro F, Hysi PG, Fahy SJ, Nag A, Hammond CJ. Optic disc planimetry, corneal hysteresis, central corneal thickness, and intraocular pressure as risk factors for glaucoma. Am J Ophthalmol. 2014;157(2):441-446. doi:10.1016/j.ajo.2013.10.017

41. Jonas JB, Holbach L. Central corneal thickness and thickness of the lamina cribrosa in human eyes. Invest Ophthalmol Vis Sci. 2005;46 (4):1275-1279. doi:10.1167/iovs.04-0851

42. Hashemi H, Yazdani K, Mehravaran S, et al. Corneal Thickness in a Population-Based, Cross-Sectional Study: the Tehran Eye Study. Cornea. 2009;28(4):395-400. doi:10.1097/ICO.0b013e31818c4d62

43. Francis BA, Varma R, Chopra V, Lai M-Y, Shtir C, Azen SP. Intraocular pressure, central corneal thickness, and prevalence of open-angle glaucoma: the Los Angeles Latino eye study. Am J Ophthalmol. 2008;146(5):741-746. doi:10.1016/j.ajo.2008.05.048

44. Pan $\mathrm{C}-\mathrm{W}$, Li J, Zhong $\mathrm{H}$, et al. Ethnic variations in central corneal thickness in a rural population in China: the Yunnan minority eye studies. PLoS One. 2015;10(8):e0135913. doi:10.1371/journal. pone. 0135913

45. Kadhim YJ, Farhood QK. Central corneal thickness of Iraqi population in relation to age, gender, refractive errors, and corneal curvature: a hospital-based cross-sectional study. Clin Ophthalmol. 2016;10:2369-2376. doi:10.2147/OPTH.S116743

46. Sng C, Barton K, Kim H, Yuan S, Budenz DL. Central corneal thickness and its associations with ocular and systemic factors in an urban west African population. Am J Ophthalmol. 2016;169: 268-275. doi:10.1016/j.ajo.2016.07.004

47. Mimouni M, Flores V, Shapira Y, et al. Correlation between central corneal thickness and myopia. Int Ophthalmol. 2018;38 (6):2547-2551. doi:10.1007/s10792-017-0766-1

48. Kleinhans S, Herrmann E, Kohnen T, Bühren J. [Comparison of discriminant analysis and decision trees for the detection of subclinical keratoconus]. Klin Monbl Augenheilkd. 2019;236(6):798-805. German 


\section{Publish your work in this journal}

Clinical Ophthalmology is an international, peer-reviewed journal covering all subspecialties within ophthalmology. Key topics include: Optometry; Visual science; Pharmacology and drug therapy in eye diseases; Basic Sciences; Primary and Secondary eye care; Patient Safety and Quality of Care Improvements. This journal is indexed on PubMed

Submit your manuscript here: https://www.dovepress.com/clinical-ophthalmology-journal
Central and CAS, and is the official journal of The Society of Clinical Ophthalmology (SCO). The manuscript management system is completely online and includes a very quick and fair peer-review system, which is all easy to use. Visit http://www.dovepress.com/ testimonials.php to read real quotes from published authors. 